\title{
Criminal Sanctions Against Publisher of Empty Giro in Polda Jateng Jurisdictions
}

\author{
Ridha Ari Setyono ${ }^{1}$ and Amin Purnawan ${ }^{2}$
}

Abstract. The research titled Criminal Sanctions Against Empty Giro Publisher in POLDA Jateng Jurisdiction. The purpose of this study: 1) To determine and analyze the implementation process of the investigation against the perpetrators of criminal sanctions Empty Giro Publisher in POLDA Jateng Jurisdiction. 2) To identify and analyze the constraints and solutions in implementation investigations against perpetrators of criminal sanctions Empty Giro Publisher in POLDA Jateng Jurisdiction. Research result : 1. Law enforcement against perpetrators of criminal acts in the form of giro checks is through the efforts of repressive. Repressive efforts are attempts made by the investigator to take action against the perpetrators of criminal acts Empty Giro in the jurisdiction of the POLDA Jateng. This is done so that the Empty Giro criminal cases can be resolved legally and thus criminal checks received appropriate punishment of what they did. 2. Factors to be obstacles in the implementation of criminal investigations Empty Giro that it is difficult unresolved criminal cases Empty Giros that internal factors and external factors: a) Internal factors include the following: 1) Personnel limited police investigator 2) Factors geographical circumstances 3) Witnesses minimum 4) lack of operational budgets investigation 5) Lack of expert investigators in handling criminal cases Empty Giros. While b) External factors, mepiputi: 1) Difficulty in finding relevant legal experts in the field of criminal fraud checks. 2) The level of public knowledge are limited in banking issues and agreements giro payment by check or giro. The efforts made by POLDA Jateng investigator in the criminal prosecution of fraud in the form of a Empty Giro and giro slip is to undertake repressive efforts. 2) The level of public knowledge are limited in banking issues and agreements giro payment by check or giro. The efforts made by POLDA Jateng investigator in the criminal prosecution of fraud in the form of a Empty Giro and giro slip is to undertake repressive efforts. 2) The level of public knowledge are limited in banking issues and agreements giro payment by check or giro. The efforts made by POLDA Jateng investigator in the criminal prosecution of fraud in the form of a Empty Giro and giro slip is to undertake repressive efforts.

Keywords: Criminal Sanctions; Empty Giro Publisher; POLDA Jateng

\section{Introduction}

Giro is securities. The term "giro" began to be used strictly in the sense of checking, established by Act No. 7 of 1992 as amended by Act No. 10 of 1998. Giro is a deposit of funds which may be withdrawn at any time by check, giro, forms of payment order or by transfer. While the giro check is a warrant from the customer to the bank

\footnotetext{
${ }^{1}$ Student of Masters (S2) of Law Faculty of Law Unissula and Ditreskrimum Polda Jateng email: ari.setyono32@gmail.com

${ }^{2}$ Lecturer of Faculty of Law Unissula Semarang
} 
depositors to transfer funds from the account written off a number of concerned to the named account holder. And provisions regulating the giro contained in Bank Indonesia Circular Letter (SEBI) dated January 24, 1972 No. 4/670 / UPPB / PbB, enhanced with: Decree of Directors No. 28/32 KEP / DIR dated July 4, 1995, Circular No. 28/32 / UPG dated July 4, 1995, Circular No. 2/10 / DASP / June 8, 2000, Circular No. 4/17 / DASP dated 7 November 2002.

For publishers who publish empty giro will receive administrative sanctions such as the inclusion of the name of the customer to the Black List Empty Giro withdrawal, as well as the customer shall return the remaining giro form that has not been used. Customer name listed in the black list expires, and then can be readmitted as a bank customer. ${ }^{3}$ However, if the issuer is no indication Empty Giro and should be assumed after the investigation turned out to be no element of fraud can be imposed criminal sanctions as provided for in the Criminal Justice Act.

Will guarantee legal certainty in the application of the principles contained in Article 1 paragraph (1) of the Criminal Code is a new person can be punished for his actions, if the criminal sanctions for actions that had been arranged earlier in the Act. In any case the evil deed, will not be penalized if there is no legislation prohibiting it and mention sanctions. (Article 1 (1) of the Criminal Code). ${ }^{4}$

The formulation of the problem in this research: How does the process of implementation of the investigations against perpetrators of criminal sanctions Empty Giro Publisher in POLDA Jateng Jurisdiction? Are the constraints and solutions in implementation investigations against perpetrators of criminal sanctions Empty Giro Publisher in POLDA Jateng Jurisdiction?

\section{Research Methods}

This type of research is used in completing this research is descriptive analysis juridical research method, the research done by researching library materials (secondary data) or legal research library, and described in the analysis and discussion.

According Soerjono Soekanto and Sri Mamudji, normative legal studies include research into the general principles of law, the degree of synchronization of the laws of the research approach The research approach used in this study is empirical legal research or so-called empirical juridical ${ }^{5}$, In this study, the law conceived as an empirical phenomenon that can be observed in real life.

The type of data that will be used in this penerlitian is the primary data, secondary and tertiary. Primary legal materials, which comprises: the Constitution of the Republic of Indonesia of 1945, Penal Code, Criminal Procedure Code, Commercial code, Decree of Bank Indonesia Number 28/32 / Kep / Dir of Giro dated July 4, 1995, Bank Indonesia Circular Letter 18 / 41 / PBI / 2016 on Giro November 29, 2016.

\footnotetext{
${ }^{3}$ Asikin Zainal 2010 Pengantar Hukum Perbankan Indonesia Rajawali Press Jakarta p. 30

${ }^{4}$ Emirzon Joni 2002 Hukum Surat Berharga dan Pekembangannya Di Indonesia Prenhallindo Jakarta p 12

${ }^{5}$ Soerjono Soekanto and Sri Mamudji 2006 the Normative Legal Research King Grafindo Persada Jakarta p. 28
} 
Secondary law which is material obtained from a variety of materials literature by studying books or literature relating to research ${ }^{6}$, Tertiary legal material, comprising: Indonesian Dictionary, English Dictionary, the Law Dictionary, Encyclopedia and the means of teaching (hand out) about the manner of writing scientific papers.

The data collection is focused on the present, so that in this study is not distorted and blurred in the discussion. This study uses the Library Research (literature study) that the collection of data obtained from sources of literature, scientific papers, legislation and other written sources relating to the matter being investigated as a theoretical basis. From this research data obtained so-called secondary data. Observation, observation of data collection and phenomena in the field prior to the study. Interviews, research through interviews with informants. Samples were taken using purposive side, ie the sampling method with the purpose and specific criteria, namely for those who berkompenten in pretrial.

Data analysis method used is normative analysis, that takes into account the facts that exist in the field of practice which are then compared with the description obtained from the study of literature. From this analysis it can be seen the effectiveness of the legal system that is instructive to the public in knowing the Criminal Sanctions Against Empty Giro Publisher POLDA Jateng Jurisdiction.

As a way to draw conclusions from the research that has been collected, data analysis method used is a qualitative Normative. Normative for this study starts from the regulations that exist as a positive legal norms, while qualitative data analysis means that the starting point on the information obtained from the respondents.

\section{Results and Discussion}

\subsection{Process Investigation Against Perpetrators of Criminal Sanctions Empty Giro Publisher in POLDA Jateng Jurisdiction}

The use of checks as a payment instrument in Indonesia in particular is often a problem, especially concerning bad checks. Check / Empty Giro Check / Giro are exposed and rejected are interested in a grace period of their obligation to provide funds by towing because of insufficient credit or the account has been closed ${ }^{7}$, Empty Giro cause harm to the people who receive it when the transaction took place. Crime in business, especially in payment transactions using checks has created problems for the work of investigators and police investigators.

According to Article 1 point 2 of the Code of Criminal Procedure Investigation is investigating a series of actions in terms and in the manner set forth in this law to search for and collect evidence that occurs in order to find the suspects. In the implementation of the investigation, the investigator has an obligation under Article 7 of the Criminal Procedure Code, namely:

- Receive reports or complaints from anyone about the crime;

- Take action first at the place of the incident;

\footnotetext{
${ }^{6}$ Soerjono Soekanto dan Sri Mamudji 2006 Penelitian Hukum Normatif Raja Grafindo Persada p 32.

${ }^{7}$ M. Bahsan 2005 Giro dan Bilyet Giro Perbankan Indonesia Raja grafindo Persada Jakarta p. 47
} 
- Telling someone to stop suspects and checking personal identification of the suspect;

- Arrest, detention, search and seizure;

- Examination of foreclosure letters;

- Fingerprinting and photographing a person suspected of committing a crime;

- Calling people to be heard and questioned as a suspect or a witness;

- Bring someone expert is required in connection with the case investigation;

- Conducting investigations termination decisions.

The efforts in the investigation of the cases of fraud using the Empty Giro, that is to call the witnesses against fraudulent use of checks. The investigation process in the jurisdiction of the POLDA Jateng still are not running optimally, because of 10 reports were dealt with there were only 2 cases until P21 stage.

Law enforcement against perpetrators of criminal acts in the form of giro checks is through the efforts of repressive. Refresif efforts are attempts made by the investigator to take action against the perpetrators of criminal acts Empty Giro in the jurisdiction of the POLDA Jateng. This is done so that the Empty Giro criminal cases can be resolved legally and thus criminal checks received appropriate punishment of what they did.

According to Article 31, paragraph 2 of Regulation Chief of Police of the Republic of Indonesia Number 12 of 2009 on the Supervision and Control Handling Criminal Cases in Environmental Police of the Republic of Indonesia, the deadline for the settlement calculated from the issuance of a warrant investigation include: 120 days for the investigation of the case is very difficult, 90 days for investigation difficult case, 60 days for investigation of the case was 30 days for investigation easy. In this case a criminal offense in the form of bank draft enipuan included in the case being,

"In terms of the investigation time limit referred to in Article 31 paragraph (1) of investigation yet to be finalized by the investigator may request an extension of time of investigation to officials who gave the orders through the Police Investigators."

But in this case was not determined how the addition and the time limit is not specified how many times the investigator may also ask for additional time for settling disputes. On the one hand this arrangement helps the performance of the investigator because it has a long enough time to complete an investigation, but the setting is what makes the criminal case of fraud in particular bank draft drawn-in stage of the investigation.

The reasons for the need for expert testimony in the investigation that the law ${ }^{8}$ :

- In terms of formal; Description lawyer is required at the level of investigation on the grounds to meet the requirements of article 184 of the Criminal Code, because it is not uncommon investigators have doubts about the legal facts found in the investigation of criminal matters. Or in other words to support the evidence that already exists.

\footnotetext{
${ }^{8}$ Hartono 2010 Penyidikan dan Penegakan Hukum Pidana Melalui Pendekatan Progresif. Sinar Grafika. Jakarta p. 65
} 
- In terms of material. The need for expert testimony law in terms of the level of investigation material is to ensure the passage in persangkakan or ascertain the facts contained in the interrogation of Article series to be presupposed.

Reality on the ground shows that expert testimony is still needed to make light of a particular criminal offense of criminal fraud in the form of bank draft checks for the crime of bank draft the formchecks require special understanding that the banking sector. Because Investigators have yet to master the science of law to specific cases which are being addressed, the role of expert testimony is crucial both for investigators or judges as the basis for consideration of each stage of the case investigation. Because the statements of experts is only one piece of evidence of 5 the evidence set out in Article 184 Criminal Procedure Code, the Position statement of the experts as well as other evidence, but have the function of making the light case for expert testified of expertise so as to obtain an understanding of the case as a whole.

\subsection{Obstacles And Solutions In Implementation Investigation Against Perpetrators of Criminal Sanctions Empty Giro Publisher in POLDA Jateng Jurisdiction}

In the process of criminal investigation of bank draft in the form of a Empty Giro in the jurisdiction of the POLDA Jateng have problems in collecting evidence, especially witnesses to be questioned in the issuance of the check is only done by both sides so as to make fraud cases difficult to resolve using Empty Giro. Therefore it is very necessary statement of experts in terms of supporting evidence of criminal fraud in the form of bank draft checks. Factors to be obstacles in the implementation of criminal investigations Empty Giro that it is difficult unresolved criminal cases Empty Giros that internal factors and external factors:

- Internal factors

Internal factors are factors originating from within the Police POLDA Jateng. These factors are:

- Personnel limited police investigators

- Factors geographical situation

- The Witnesses minimum

- The lack of an operating budget of investigation

- Lack of expert investigators in handling criminal cases Empty Giros.

- External factors

- Difficulty in finding relevant legal experts in the field of criminal fraud checks.

- The level of public knowledge are limited in banking issues and agreements giro payment by check or giro.

Refresif efforts that have been made POLDA Jateng investigators to take action against criminal suspects fraud in the form of giro checks continue to do so as a Empty Giro criminal punishment proportionate to what he had done.

\section{Closing}

\subsection{Conclusion}


- Law enforcement against perpetrators of criminal acts in the form of giro checks is through the efforts of repressive. Refresif efforts are attempts made by the investigator to take action against the perpetrators of criminal acts Empty Giro in POLDA Jateng jurisdiction. This is done so that the Empty Giro criminal cases can be resolved legally and thus criminal checks received appropriate punishment of what they did.

- Factors to be obstacles in the implementation of criminal investigations Empty Giro that it is difficult unresolved criminal cases Empty Giros that internal factors and external factors: 1) Internal factors. Internal factors are factors originating from within the Police POLDA Jateng. These factors are: a) Personnel limited police investigators; b) Factors geographical situation; c) The Witnesses minimum; d) The lack of an operating budget of investigation; e) Lack of expert investigators in handling criminal cases Empty Giros; 2) External factors: a) Difficulty in finding relevant legal experts in the field of criminal fraud checks; b) The level of public knowledge are limited in banking issues and agreements giro payment by check or giro. The efforts made by POLDA Jateng investigator in the criminal prosecution of fraud in the form of a Empty Giro and giro slip is to undertake repressive efforts.

\subsection{Suggestion}

- Should law enforcement officers in Central Java regional police take action unequivocally any act of fraud cases in the form of bank draft checks, giro and current accounts so that the investigation can run well.

- Should a need to increase the number of personnel Investigator, Investigator operating budget additions, upgrades investigators through specialized training in the banking sector in the fight against criminal fraud in the form of bank draft checks, giro and current accounts.

\section{References}

[1] Asikin Zainal 2010 Pengantar Hukum Perbankan Indonesia Rajawali Pers. Jakarta.

[2] Bank Indonesia Circular Letter 18/41 / PBI / 2016 on Giro November 292016

[3] Bank Indonesia Decree No. 28/32 / Kep / Dir of Giro dated July 41995.

[4] Commercial code.

[5] Constitution of the Republic of Indonesia of 1945.

[6] Criminal Code.

[7] Criminal Procedure Code.

[8] Emirzon Joni 2002 Hukum Surat Berharga dan Pekembangannya Di Indonesia Prenhallindo Jakarta.

[9] Hartono 2010 Penyidikan dan Penegakan Hukum Pidana Melalui Pendekatan Progresif Sinar Grafika Jakarta.

[10] M. Bahsan 2005 Giro dan Bilyet Giro Perbankan Indonesia Raja Grafindo Persada Jakarta.

[11] Soerjono Soekanto 2005 Pengantar Penelitian Hukum Jakarta : Rineka Cipta. 
[12] Soerjono Soekanto dan Sri Mamudji 2006 Penelitian Hukum Normatif Raja Grafindo Persada Jakarta. 